\title{
Cerebrovascular and Neurological Dysfunction under the Threat of COVID-19: Is There a Comorbid Role for Smoking and Vaping?
}

\author{
Sabrina Rahman Archie ${ }^{1}$ and Luca Cucullo ${ }^{1,2, *(D)}$ \\ 1 Department of Pharmaceutical Sciences, Texas Tech University Health Sciences Center, \\ Amarillo, TX 79106, USA; Sabrina.Archie@ttuhsc.edu \\ 2 Center for Blood-Brain Barrier Research, Texas Tech University Health Sciences Center, \\ Amarillo, TX 79106, USA \\ * Correspondence: luca.cucullo@ttuhsc.edu; Tel.: +806-414-9237
}

Received: 10 May 2020; Accepted: 29 May 2020; Published: 30 May 2020

\begin{abstract}
The recently discovered novel coronavirus, SARS-CoV-2 (COVID-19 virus), has brought the whole world to standstill with critical challenges, affecting both health and economic sectors worldwide. Although initially, this pandemic was associated with causing severe pulmonary and respiratory disorders, recent case studies reported the association of cerebrovascular-neurological dysfunction in COVID-19 patients, which is also life-threatening. Several SARS-CoV-2 positive case studies have been reported where there are mild or no symptoms of this virus. However, a selection of patients are suffering from large artery ischemic strokes. Although the pathophysiology of the SARS-CoV-2 virus affecting the cerebrovascular system has not been elucidated yet, researchers have identified several pathogenic mechanisms, including a role for the ACE2 receptor. Therefore, it is extremely crucial to identify the risk factors related to the progression and adverse outcome of cerebrovascular-neurological dysfunction in COVID-19 patients. Since many articles have reported the effect of smoking (tobacco and cannabis) and vaping in cerebrovascular and neurological systems, and considering that smokers are more prone to viral and bacterial infection compared to non-smokers, it is high time to explore the probable correlation of smoking in COVID-19 patients. Herein, we have reviewed the possible role of smoking and vaping on cerebrovascular and neurological dysfunction in COVID-19 patients, along with potential pathogenic mechanisms associated with it.
\end{abstract}

Keywords: SARS-CoV-2; COVID-19; cerebrovascular; neurological; smoking; CNS; blood-brain barrier

\section{Introduction}

Coronavirus disease 2019 or COVID-19 is an infectious disease caused by a recently discovered form of coronavirus known as severe acute respiratory syndrome coronavirus-2 (SARS-Cov-2) [1,2]. The outbreak of this virus first appeared in Wuhan city of Hubei province in China in December 2019 [3]. On March 11, 2020, it was declared as a pandemic by the World Health Organization (WHO) [4]. As of May 28th 2020, a total number of 5,792,874 coronavirus cases, including 357,479 deaths, have been reported all over the world [5]. This virus is spreading among all populations so rapidly that, in just three months, the USA has become the epicenter, having 1,745,803 confirmed cases, including 102,107 deaths. The number of confirmed cases seems to indicate a steady increment over time and these numbers can be forecasted using several mathematical models available for COVID-19 [5-8].

Coronaviruses belong to the subfamily Coronavirinae (family Coronaviridae; order Nidovirales), containing four genera named, Alphacoronavirus, Betacoronavirus, Gammacoronavirus, and Deltacoronavirus [9]. SARS-CoV-2 is a Betacoronavirus closely related to other human pathogenic 
coronaviruses SARS-CoV and MERS-CoV that also emerged in the 21st century [10]. SARS-CoV-2 is an enveloped and non-segmented single-stranded positive-sense RNA virus having crown like spikes on the outer surface. The diameter and length of SARS-CoV-2 are about $65-125 \mathrm{~nm}$ and $29.9 \mathrm{~kb}$ respectively [11,12]. Structure of SARS-CoV-2 consists of 4 major proteins namely, spike (S) glycoprotein, envelope (E) glycoprotein, membrane (M) glycoprotein, and nucleocapsid (N) protein, as well as several non-structural and accessory proteins (see Figure 1). Among all the proteins, the spike (S) protein plays a key role in viral attachment, fusion, entry, and transmission. This $S$ protein is responsible for the entry of SARS-CoV-2 into the host cell by attaching with angiotensin converting enzyme 2 (ACE2), which acts as a receptor and is present in different organs of the body $[13,14]$.

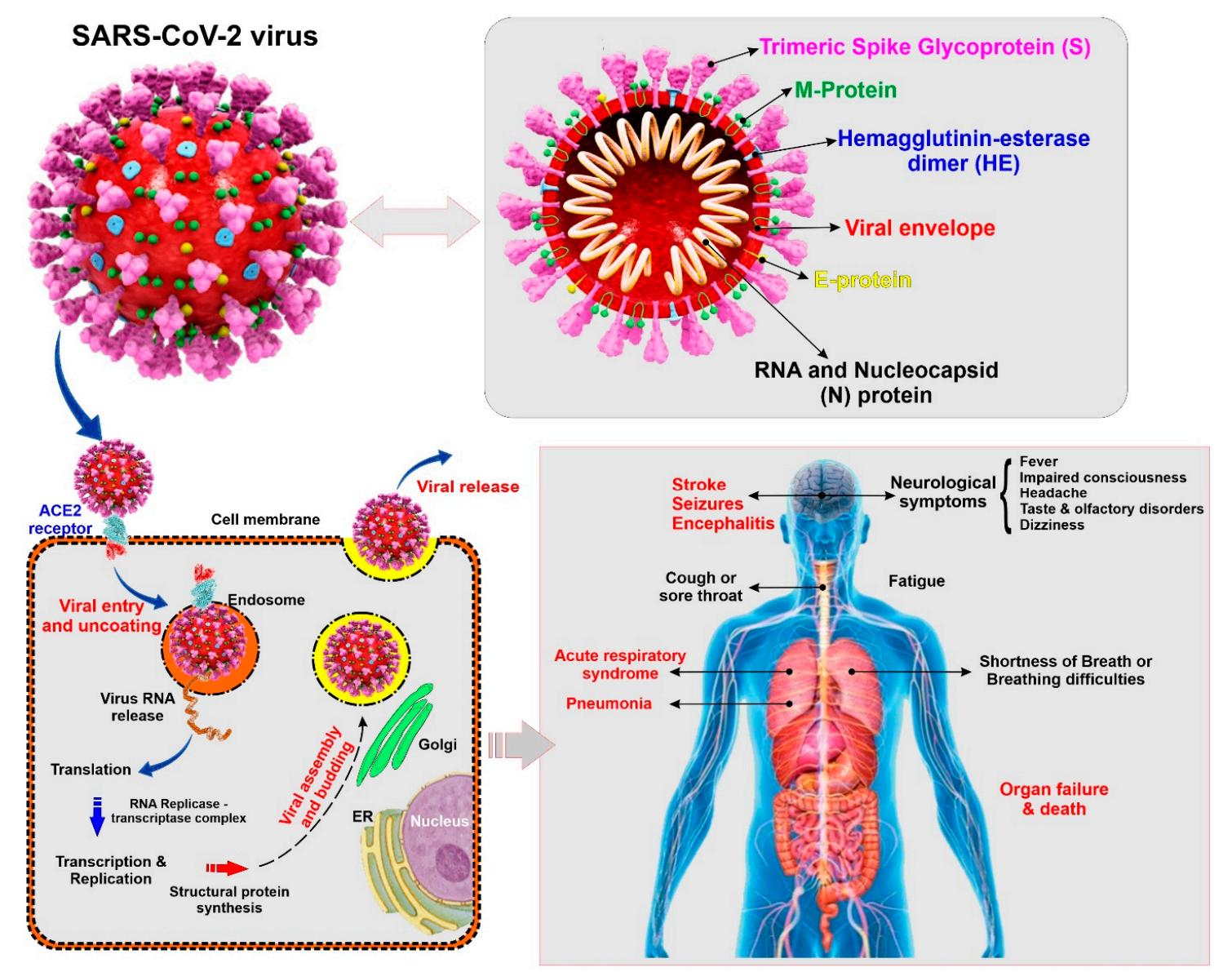

Figure 1. Illustrative view of the SARC-CoV-2 virus structural components and known modality of viral entry into the cells. The scheme also provides a summary panel of the potential health impact on the human body specific to lung and the CNS. (ACE2: Angiotensin converting enzyme 2, ER: Endoplasmic reticulum)

COVID-19 is easily transmitted through saliva droplets or discharge from the nose of an infected person when he/she sneezes or coughs $[15,16]$. While most of the infected patients will show mild to moderate respiratory distress/illness and recover with or without requiring special treatments, the death toll number is shockingly high compared to other types of coronaviruses, SARS-CoV and MERS-CoV. The symptoms include fever, dry cough, shortness of breath, sore throat, tiredness, and aches and pains [2]. The Centers for Disease Control and Prevention (CDC) have identified some severe symptoms which require emergency medical attention including, but not limited to, persistent pain or pressure in the chest, trouble breathing, inability to wake or stay awake, new confusion, and bluish lips or face [17]. Although COVID-19 primarily affects the respiratory system, recent reports have revealed some neurological and cerebrovascular symptoms associated with the disease, including 
headache, disturbed consciousness, paresthesia [1], and, most recently, stroke [18]. Additionally, brain tissue edema and partial neuronal degeneration, as well as viral encephalitis attacking the central nervous system (CNS) have also been reported $[19,20]$. Therefore, it seems that COVID-19 can promote harm of the cerebrovascular system and the CNS of infected patients.

Smoking (cigarettes and cannabis) and vaping are significant public health concerns in the USA and around the globe. Ample studies have found that smoking is associated with different diseases affecting different organs of the body, many of which are fatal. Smoking is considered a risk factor for developing and progression of cancers and major forms of respiratory distress, including chronic obstructive pulmonary disease (COPD), pulmonary fibrosis etc. [21]. It has been reported that smoking is responsible for the development of squamous metaplasia in large airways, hypersecretion of mucus and hyperplasia in smooth muscle, along with increased small airway fibrosis and thickening of the airway wall which ultimately results in narrowing and destruction of the airway, accompanied by bronchitis. Patients may also suffer from airflow limitation due to emphysematous lung destruction [22]. Smoking is also considered a significant pro-immunogenic mix of substances impacting the immune responses and promoting the onset of autoimmune disorders (such as rheumatoid arthritis and systemic lupus) in genetically-susceptible individuals. Smoking severely impacts the vascular system promoting the onset of neurological diseases as well as fatal cardiovascular diseases [23]. By comparison with non-smokers, smokers are more prone to respiratory illness, including colds, increased rates of influenza, bacterial pneumonia, and tuberculosis [24]. Smoking causes damage to the lungs which, in turn, makes the patients more vulnerable to viral and bacterial pulmonary infections as well. Tobacco smoke causes structural changes, including peri-bronchiolar inflammation and fibrosis, enhanced mucosal permeability, impaired mucociliary clearance, changes in pathogen adherence, and disruption of the respiratory epithelium, which ultimately dysregulate immune defenses of respiratory system. Moreover, smoking is related to a wide range of alterations in cellular and humoral immune system function [25].

In comparison to non-smokers, smokers have an increased risk of developing influenza [25] and this infection can even exacerbate the comorbidities that are common in these populations [26]. It has also been reported that, after influenza infection, smokers are at higher risk of hospitalization compared to non-smokers [27]. Tobacco smoke not only plays a crucial role in developing respiratory distress but is also associated with an increased risk of cerebrovascular and neurological diseases, like stroke, Alzheimer's disease, multiple sclerosis, and vascular dementia by disrupting the blood-brain barrier (BBB), inducing oxidative stress, inflammation, and the alteration of immune responses [28-31]. Noticeably, the negative effect of smoking on the progression of COVID-19 infection has been reported in recent case studies and reports [32-35]. As smoking increases the risk and susceptibility of SARS-CoV-2 infection, increasing the progression of COVID-19, and leading to severe respiratory distress and cardiovascular disease, this review article aims to determine plausible comorbid CNS and cerebrovascular roles of smoking and vaping in COVID-19 patients.

\section{CoV Infection and CNS}

Previous studies reported the disruption of the structure and function of the CNS due to viral infection resulting in severe encephalitis, toxic encephalopathy, and severe acute demyelinating lesions $[1,36]$. Some neurotropic viruses can cause infections of macrophages, microglia, and astrocytes by invading nervous tissues $[37,38]$. It is evident from previous studies that respiratory-related infections act as a critical factor for developing the acute cerebrovascular disease $[39,40]$ Moreover, the influenza virus has been found to exacerbate ischemic brain injury through initiating cytokine cascade, thus increasing the probability of tissue-type plasminogen activator mediated cerebral hemorrhage [41].

SARS-CoV was found to cause different neurological diseases, including encephalitis, polyneuropathy, and large artery ischemic stroke [42]. Subsequently, the occurrence of cerebral edema and meningeal vasodilation along with the presence of the SARS-CoV genome sequence were identified in the brain of several SARS cases from autopsy studies [1,43]. Moreover, monocyte and 
lymphocyte penetration in the vessel wall, ischemic changes of neurons, and nerve fiber demyelination were also detected in autopsies of brain samples of the infected patients [43,44].

MERS-CoV, another coronavirus, causes Middle East Respiratory Syndrome or MERS and is known as neuroinvasive. It has been found from different studies that MERS-CoV is also responsible for causing different neurological complications, including insanity, seizures, ischemic stroke, paralysis, disturbed consciousness, Guillain-Barre syndrome, and other poisoning or infectious neuropathy [45,46].

\section{Neurological and Cerebrovascular Manifestations of COVID-19}

SARS-CoV-2, the responsible virus for COVID-19, is 79.5\% genetically similar to SARS-CoV and $96 \%$ similar to bat coronavirus [47]. The sequence homology of SARS-CoV-2 also showed a $50 \%$ similarity to MERS-CoV virus [48]. Although the primary symptoms of COVID-19 include fever, dry cough, and fatigue in most of the patients [33], some COVID-19 patients exhibited sole neurological symptoms including headache, dizziness, languidness, unstable walking, malaise, cerebral hemorrhage, and infarction without showing any of the typical COVID-19 symptoms [49]. Additional studies have also reported a sudden loss of smell or taste in some COVID-19 patients as well [50,51].

A current study comprising 214 patients demonstrated that $36.45 \%$ of patients of the total cohort showed neurological symptoms, including acute cerebrovascular disease, impairment of consciousness, and skeletal muscle motor function disability; $18.7 \%$ of total admitted patients had these severe neurological manifestations and required admission to the intensive care unit $[49,52]$. Other case studies (shown in Table 1) also reported that acute cerebrovascular and neurological symptoms, including headache, dizziness, impaired consciousness, olfactory disorders, have been found in COVID-19 patients. Table 1 summarizes recent case studies related to COVID-19 and neurological dysfunction. However, one of the limitations of the case studies is that the analysis of cerebrospinal fluid (CSF) and electroencephalography (EEG) was not performed to confirm the presence of the virus in the CSF [53].

Another recent report has also shown COVID-19 to causes sudden stroke in patients aged between 30 and 40 years old. Although these COVID-19 infected patients had mild or no symptoms of COVID-19, abnormal blood clotting in large arteries has been reported, which ultimately resulted in severe stroke [18].

Another important finding is the detection of the genome sequence of SARS-CoV-2 in cerebrospinal fluid, which opens up a direction towards the damage of CNS in COVID-19 patients causing viral encephalitis [1]. Moreover, some of the COVID-19 patients were found to suffer from viremia and hypoxia [59], which play a crucial role in developing toxic encephalopathy. The occurrence of headache, disturbance in consciousness, other neurological dysfunction is close to $40 \%$ of COVID-19 patients [60], and the concurrent detection of brain tissue edema seems to suggest the existence of a possible link between COVID-19 and infectious, toxic encephalopathy [19]. However, extensive studies need to be conducted to validate this hypothesis further. Additionally, it has been reported that SARS-CoV-2 can initiate a cytokine storm mechanism, which may lead to a range of infectious and non-infectious diseases, including pancreatitis, acute cerebrovascular disease, and multiple organ dysfunction [61-63]. Critically-infected patients also showed a high level of $\mathrm{D}$ dimer and severe reduction in platelets, which may make the patients more vulnerable to acute cerebrovascular dysfunction [60,64]. Additionally, it has been speculated that COVID-19 positive patients are vulnerable to other types of pathogenic bacteria, which can damage the integrity of the blood-brain barrier (BBB). Subsequently, this secondary infection may lead to headaches, vomiting, loss of vision, and limb convulsions in COVID-19 patients [1].

Focusing on current case studies and research on COVID-19 patients, it is evident that COVID-19 could be associated with neurological and cerebrovascular dysfunction, which can be life-threatening as well. 
Table 1. Case studies on neurological and cerebrovascular symptoms in COVID-19 patients.

\begin{tabular}{|c|c|c|c|c|}
\hline Study Type & Time & Study Design & Outcome and Symptoms & Reference \\
\hline $\begin{array}{l}\text { Retrospective } \\
\text { case series }\end{array}$ & $\begin{array}{c}13 \text { January to } 31 \\
\text { March }\end{array}$ & $\begin{array}{c}\quad N=274 \\
\text { admitted patients }\end{array}$ & $\begin{array}{l}\text { Headache }(11.31 \%), \\
\text { Dizziness }(7.66 \%)\end{array}$ & {$[54]$} \\
\hline $\begin{array}{l}\text { Retrospective } \\
\text { case series }\end{array}$ & $\begin{array}{l}16 \text { January } 2020 \text { to } \\
29 \text { February } 2020\end{array}$ & $\begin{array}{c}N=221 \\
\text { admitted patients }\end{array}$ & $\begin{array}{c}\text { Acute ischemic stroke }(5 \%), \\
\text { CVST }(0.5 \%), \text { cerebral } \\
\text { hemorrhage }(0.5 \%)\end{array}$ & [55] \\
\hline $\begin{array}{l}\text { Retrospective } \\
\text { case series }\end{array}$ & $\begin{array}{l}16 \text { January } 2020 \text { to } \\
19 \text { February } 2020\end{array}$ & $\begin{array}{c}\quad N=214 \\
\text { admitted patients }\end{array}$ & $\begin{array}{c}\text { Nervous system symptoms } \\
(36.4 \%) \text { including CNS } \\
\text { symptoms }(24.8 \%): \\
\text { (Headache }(13.1 \%) \text {, dizziness } \\
(16.8 \%), \text { impaired consciousness } \\
(7.5 \%), \text { acute cerebrovascular } \\
\text { disease }(2.8 \%) \text {, ataxia }(0.5 \%), \\
\text { epilepsy }(0.5 \%))\end{array}$ & [52] \\
\hline $\begin{array}{l}\text { Retrospective } \\
\text { case series }\end{array}$ & $\begin{array}{l}1 \text { January to } 28 \\
\text { January, } 2020\end{array}$ & $\begin{array}{c}N=\underset{\text { patients }}{138 \text { admitted }} \\
\text { paid }\end{array}$ & Headache $(7 \%)$, dizziness (9\%) & {$[56]$} \\
\hline $\begin{array}{l}\text { Retrospective } \\
\text { case series }\end{array}$ & $\begin{array}{l}\text { 1 January to } 20 \\
\text { January, } 2020\end{array}$ & $\begin{array}{c}N=99, \text { admitted } \\
\text { patients }\end{array}$ & Headache $(8 \%)$, confusion $(9 \%)$ & [57] \\
\hline $\begin{array}{l}\text { Cross-sectional } \\
\text { survey }\end{array}$ & 19 March, 2020 & $\begin{array}{c}N=59, \text { admitted } \\
\text { patients }\end{array}$ & $\begin{array}{c}\text { Headache }(3.4 \%) \\
\text { Taste or olfactory disorder } \\
(33.9 \%), \\
\text { Taste and olfactory disorder } \\
(18.6 \%)\end{array}$ & {$[50]$} \\
\hline $\begin{array}{l}\text { Retrospective } \\
\text { case series }\end{array}$ & $\begin{array}{c}\text { late December } \\
\text { 2019- 26 Jan } 2020\end{array}$ & $\begin{array}{l}N=52, \text { admitted } \\
\text { patients (critically } \\
\text { ill adults) }\end{array}$ & Headache $(6 \%)$ & [58] \\
\hline $\begin{array}{l}\text { Prospective } \\
\text { case series }\end{array}$ & By 2 January 2020 & $\begin{array}{c}N=41, \text { admitted } \\
\text { patients }\end{array}$ & Headache $(8 \%)$ in 38 patients & [33] \\
\hline Case study & 23 March to 7 April & $N=5$ & Large-vessel stroke $(100 \%)$ & [18] \\
\hline
\end{tabular}

\section{Pathophysiology of COVID-19 Related Cerebrovascular and Neurological Dysfunction}

Although the underlying mechanism behind cerebrovascular and neurological dysfunction in COVID-19 patients has not been elucidated yet, several potential mechanisms could be non-exclusively responsible for the identified comorbidities. One of the critical targets of SARS-CoV-2 is Angiotensin-converting enzyme 2 (ACE2) [49], which is present in different organs including lung, heart, kidney, testis as well neurons and glial cells of the brain [13,65-67]. ACE2 plays a pivotal role in the regulation of blood pressure as well as anti-atherosclerosis mechanisms [68]. It has been demonstrated from various studies that different types of $\mathrm{CoV}$ and influenza viruses may elevate blood pressure and increase the potential risk of cerebral hemorrhage by binding to ACE2. A recent study has also reported that SARS-CoV-2 enters into the host cell through the interaction of SARS-CoV-2 coat protein SPIKE or (S protein) with ACE2 present on the host cell resulting in the internalization of the virus [69-71]. The expression of ACE2 is found to be low in hypertensive patients, which increases the chance of hemorrhagic occurrence. Since SARS-CoV-2 decreases the ACE2 expression [72] it can be speculated that the SARS-CoV-2 infected patients are at high risk of hemorrhagic stroke (see Figure 1).

Additionally, COVID-19 patients suffer from coagulopathy and prothrombin time prolongation, which may contribute to secondary cerebral hemorrhage, although, as of today, no secondary cerebral hemorrhage has been reported in COVID-19 patients [49]. Moreover, an increased level of D-dimer has been found in COVID-19 patients, which may result in thrombotic vascular events [49,73]. As SARS-CoV-2 has been found in cerebrospinal fluid, it is crucial to evaluate the protective role of the $\mathrm{BBB}$ in preventing the virus from getting access to neural tissues [67]. This is of crucial importance 
since comorbid pathologies (such as those promoted by chronic smoking and vaping $[28,31,74,75]$ ) that negatively impact the integrity and function of the BBB may facilitate the virus entry into the CNS.

Another important mechanism behind the cerebrovascular and neurological symptoms in COVID-19 patients could be an immune injury. It has been found that viral infection may damage the nervous system by altering the immune responses [76]. A CoV infection-mediated severe pneumonia could promote systemic inflammatory response syndrome (SIRS). Studies suggested that immune damage could be prevented by early anti-inflammatory intervention and could also decrease the risk of nervous system injury [61,77]. Both SARS and COVID-19 have been found to cause multiple organ failure-mediated fatalities through virus-induced SIRS or SIRS-like immune disorders [62,78].

Cytokines play a pivotal role in regulating immunological and inflammatory function of the body [79]. Additional studies confirmed the release of high level of inflammatory factors, such as interleukin-6 (IL-6), interleukin-12 (IL-12), interleukin-15 (IL-15), and tumor necrosis factor- $\alpha$ (TNF- $\alpha$ ) from primary glial cells infected with CoV [80]. Recently, Wan et al. reported the correlation of IL-6 with the severity of COVID-19 symptoms [81]. IL-6 may act as a potential biomarker of SARS-CoV-2 as IL-6 level has been found to be increased in COVID-19 patients [79] As CoV infection can infect macrophages, microglia, and astrocytes in the CNS inducing pro-inflammatory conditions [82] and activation of immune cells, it is crucial to find the probable correlation between COVID-19 and neurological damage through immune injury.

Moreover, the proliferation of viruses in the lung tissue may lead to an impaired exchange of alveolar gas, thus triggering hypoxia in CNS. This hypoxia causes anaerobic metabolism in brain cells, which accumulates acid causing cerebral vasodilation, brain cells swelling, interstitial edema, blockage of cerebral blood flow, and headache because of ischemia and congestion [83]. Untreated hypoxia may induce acute cerebrovascular disease encompassing acute ischemic stroke in high-risk COVID-19 patients [1]. As COVID-19 patients often suffer from fatal silent hypoxia, it requires substantial examination and consideration [84]. Additionally, ACE2 also plays a role in controlling inflammatory and atherosclerosis responses of vessels [85]. Thus, COVID-19 may promote atherosclerosis formation, which ultimately may result in brain ischemic stroke by affecting brain microcapillaries.

A neurotrophic virus can also enter the CNS through neuronal pathways such as the olfactory neuron transport system. Studies reported that, in the early stage of infection or nasal vaccination, $\mathrm{CoV}$ could reach the brain through the olfactory tract, thus causing inflammation and demyelination $[1,86,87]$. Therefore, it is evident that $\mathrm{CoV}$ viruses can invade the brain by neuronal pathways, and this mechanism should also be investigated in the case of SARS-CoV-2.

\section{Smoking, COVID-19, and Cerebrovascular-Neurological Diseases}

Tobacco smoking is responsible for a wide range of diseases affecting different organs of the body, including cerebrovascular, cardiovascular, pulmonary systems, and this can be life-threatening as well [88]. These diseases include, but are not limited to, lung cancer, chronic obstructive pulmonary disease (COPD), cardiovascular diseases, stroke, and decreased immune function [89]. Yearly, tobacco smoking (TS) kills around 6 million people in the world, and more than 0.48 million people in the USA alone [90]. Although the main addictive component of TS is nicotine, it also contains more than 4700 toxic compounds encompassing carcinogens, mutagens, stable and unstable free radicals as well as reactive oxygen species (ROS). Different studies demonstrated the association between tobacco smoke and cerebrovascular-neurological dysfunction, including ischemic stroke, Alzheimer's diseases, multiple sclerosis, abnormal brain development, and vascular dementia [28,90-92]. The mechanisms behind the toxic effects of smoking include, but are not limited to, inflammation, oxidative stress, atherosclerosis, disruption of the BBB, and hyperactive immune response $[29,30]$.

The BBB plays a pivotal role in maintaining brain homeostasis and acts as a strong shield to prevent the entrance of the potentially harmful substances from system blood circulating into the brain parenchyma. Moreover, it protects the brain by limiting the body's peripheral immune defense system from entering inside the brain parenchyma [74]. Therefore, disruption of BBB integrity may expose the 
brain temporarily to potential hazardous components (both exogenous and endogenous) circulating in the blood, which may affect neuronal activities both in the CNS and the periphery [74,93]. Loss of BBB viability may, in turn, increase the risk for secondary brain damage and may progress the pathogenesis of a variety of CNS diseases such as epilepsy, silent cerebral infarction, hemorrhagic and non-hemorrhagic stroke, small vessel ischemic disease, and traumatic brain injury [74,94-97]. Different studies reported that TS causes endothelial dysfunction and damages the vascular system. TS acts as an inflammatory agent causing oxidative stress, which may be responsible for impairment of BBB [98-101]. Even at low concentrations, TS induces strong vascular pro-inflammatory responses. These encompass the upregulation of endothelial pro-inflammatory genes, pro-inflammatory cytokines such as Interleukin $-1 \beta$ (IL-1 $\beta$ ), TNF- $\alpha$, upregulation, and activation of matrix metalloproteinase- 2 and -9 (MMP-2, MMP-9), and monocyte differentiation into macrophages [31,74]. MMP-2 and MMP-9 affect BBB integrity by degrading basal laminal components and facilitating immune cell trafficking into the brain [102]. All of these pathogenic events promote BBB dysfunction and breakdown, which increases the risk of cerebrovascular disease, including stroke and other neurological disorders [31,74]. Howkins et al. reported the downregulation of zonula occludentes-1 (ZO-1; a tight junction-TJ-accessory protein linking the TJs to the cellular actin cytoskeleton) at the BBB by nicotine, causing increased BBB permeability [103]. Additionally, other scientific studies demonstrated the a7nAChR mediated alteration of the function of $\mathrm{BBB} \mathrm{Na}{ }^{+} \mathrm{K}^{+} 2 \mathrm{Cl}^{-}$co-transporter by nicotine [104-106]. TS is also associated with the progression of atherosclerosis and angiogenesis [90]. Signal transducer and activator of transcription-3 (STAT-3) is an angiogenesis modulator that acts by IL-6/STAT-3 signaling mechanism and can be upregulated by TS [107]. TS may also upregulate Apo-lipoprotein E genes, which regulate the metabolism of lipoprotein and is related to increased cholesterol level [90]. This later can further elevate the risk of ischemic stroke and atherosclerosis. Serum Amyloid A1 (SAA1) gene expression can also be upregulated by TS, which may subsequently increase the BBB permeability $[108,109]$.

Furthermore, tobacco smoke also generates a high amount of superoxide, hydrogen peroxide, hydroxyl radical, and peroxynitrite, which exposes endothelial cells to highly reactive oxygen species (ROS), leading to oxidative stress (OS) damage [110]. OS ultimately results in lipoperoxidation of polyunsaturated fatty acids in membrane lipids, protein oxidation (backbone fragmentation), DNA breakdown [111-113], mutations of the nuclear protein p53, carcinogen-mediated DNA damage, RNA oxidation, mitochondrial depolarization, dysregulation of iron transporters and detoxifying enzymes, and apoptosis $[28,114]$. These pathological effects may further impair the cerebrovascular integrity and function, along with other factors or infectious agents that affect BBB $[28,74,75,100,101]$.

Smokers are more vulnerable to bacterial and viral inflammatory neuropathologies compared to non-smokers [88] and have been shown to promote cerebral vasodilation along with reduced BBB integrity. Therefore, it is not surprising that chronic smokers are more susceptible to CNS disorders and, overall, neuronal damage caused by infection $[115,116]$. It has also been shown that the post-deep brain stimulation neuronal infection rate is higher in smoking patients compared to the non-smoking patients [117]. These observed detrimental effects in smokers could be caused by several mechanisms like increased inflammation and ROS, which leads to leaky BBB, and increased expression of receptors that promote virus invasion into the brain parenchyma. Recently, Brake et al. reported that smoking can upregulate the ACE2 receptor [24], which acts as a binding site for the S protein of SARS-CoV, coronavirus NL63, and SARS-CoV-2. This is the first immunohistochemical human lung evidence for ACE2 receptor expression in smokers and patients with COPD which identified the increased level of ACE2 expression in resected lung tissue from patients with COPD and healthy lung function smokers while entirely absent in healthy non-smoking individuals. As COPD patients showed significantly higher levels of ACE2, suggesting that COPD further exaggerates ACE2 and potential SARS-CoV-2 adhesion site [24]. Another recent study demonstrated the dose-dependent upregulation of ACE2 in a subset of epithelial cells lining the respiratory tract which includes goblet cells, club cells, and alveolar type 2 cells by cigarette smoke. This study also suggested that, smokers are more likely to develop SARS-CoV-2 infection compared to non-smokers [118]. Moreover, a recent in vitro study has 
shown that SARS-CoV-2 can infect engineered human blood vessels organoids, and this interaction can be inhibited by human recombinant soluble ACE2 (hrsACE2) antibody, thus highlighting a possible venue to treat COVID-19 [119].

In addition to lung, kidney, heart, and intestine, this receptor is also expressed in endothelial cells, glial cells, and neurons, which could increase the risk and progression of COVID-19 [120,121]. Thus the cerebral involvement of COVID-19 can result from the dissemination of the virus into the systemic circulation from the infected organ, which has been reported in other SARS-CoV affected patients [122]. Impaired BBB due to chronic smoking may facilitate the entry of the SARS-CoV-2 virus into brain parenchyma. Later, this invading virus can interact with neuronal and glial ACE2 receptors and start a viral proliferation cycle, which ultimately causes neuronal damage as previously observed in SARS-CoV [122]. Therefore, it can be reasonably speculated that smoking may enhance the risk for COVID-19 by upregulating the ACE2 [24] and promoting the loss of BBB integrity and viability (see Figure 2).

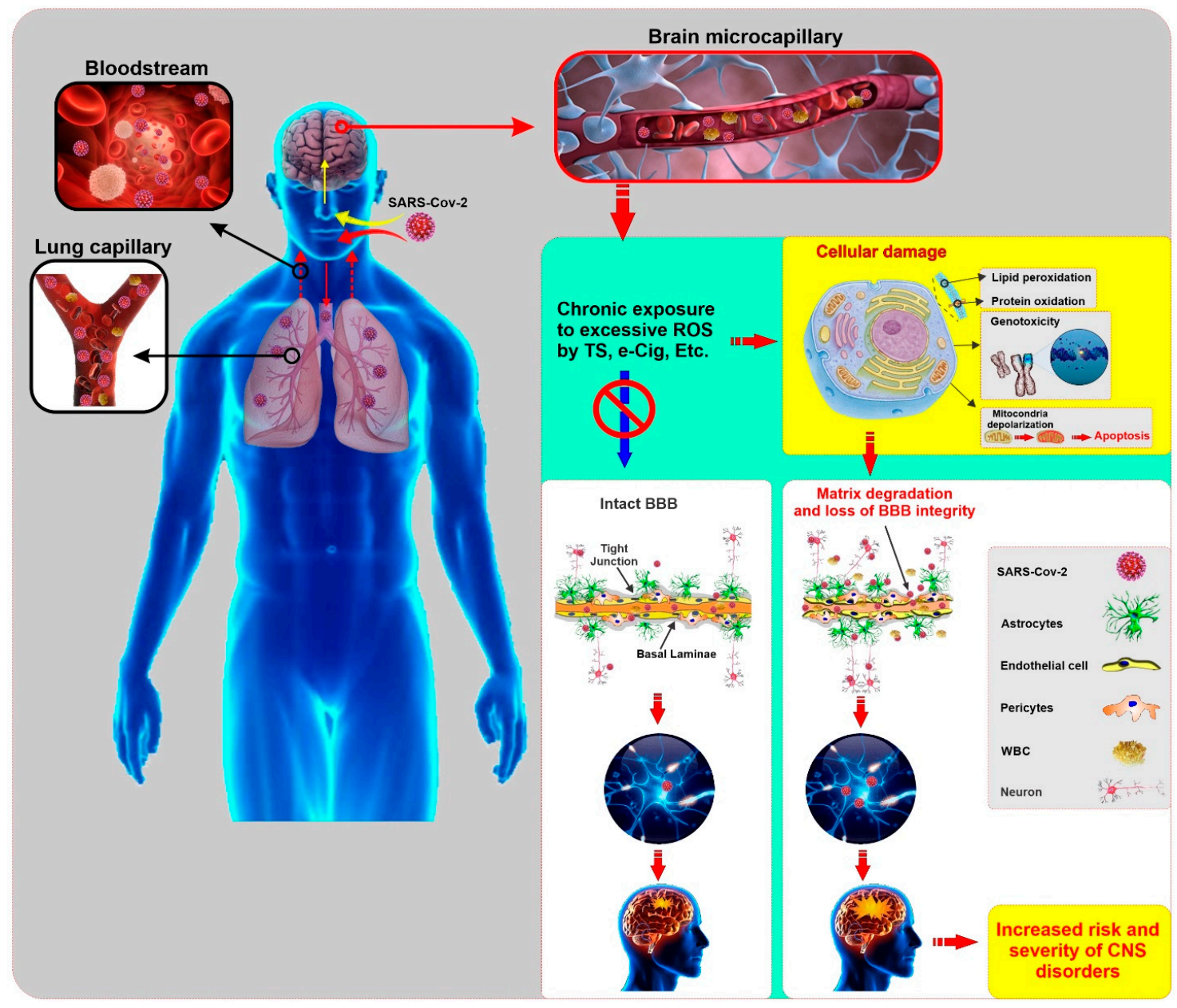

Figure 2. Illustrative panel summarizing the SARS-CoV-2 entry into the human body and the potential impact of comorbid smoking and/or vaping on the harmful effects of the viral infection to the CNS. Pre-existing conditions that impairs the viability and function of the BBB (such as those associated with chronic smoking and/or vaping) may facilitate viral entry into the brain, thus increasing the risk of onset and severity of CNS disorders. (ROS: Reactive Oxygen Species, TS: Tobacco Smoke, e-cig: electronic cigarette, BBB: Blood Brain Barrier, WBC: White Blood Cell, CNS: Central Nervous System)

In addition to ACE2, another crucial pro-coagulant factor, von Willebrand factor (VWF), is upregulated in COVID-19 patients $[123,124]$. On top of that, previous epidemiological studies have shown that smoking increases the circulatory level of VWF. VWF is a glycoprotein and exclusively 
synthesized by endothelial cells and megakaryocytes. Functionally, VWF is responsible for carrying factor VIII in blood circulation and also mediates initial platelet adhesion to the subendothelium through glycoprotein Ib-IX complex after inflammation and injury [125]. In addition to VWF upregulation, smoking has been recently shown to promote the downregulation of thrombomodulin $[75,126]$. Thrombomodulin acts as an anticoagulant factor by binding to thrombin and use its enzymatic activities to degrade factor $\mathrm{V}$, thus blocking the prothrombinase complex. The ultimate effect is a significant alteration of the blood homeostasis with a significant propensity toward blood coagulation and an increase in the risk of ischemic disorders like stroke $[127,128]$. Additionally, microthrombi were found in the circulation of several organs in COVID-19 patients, which has been claimed to be generated due to the dissemination of intravascular coagulation (DIC) [129-131]. Thus, it is highly likely that these microthrombi can also reside inside the microvascular system of the CNS and ultimately results in neurological complications. As smoking can increase the level of VWF and decrease the level of thrombomodulin, there could be a correlation between smoking and stroke occurrence in COVID-19 patients. However, extensive well-designed and controlled animal experiments are required to confirm this hypothesis.

Additionally, a recent study has suggested that smoking may promote cellular uptake of SARS CoV-2 virus through $\alpha 7 \mathrm{nAChR}$ signaling mechanism. As $\alpha 7 \mathrm{nAChR}$ is present both in neuronal and non-neuronal cells, therefore it can be said that, smoking may play a vital role in pathophysiology of SARS-CoV-2 and may affect different organs of the body including brain [132].

\section{Vaping (E-Cigarette), COVID-19, and Cerebrovascular-Neurological Diseases}

At the present time, electronic cigarettes, or e-cigarettes, have become extremely popular among youth on the pretense to be a safe alternative to tobacco smoke. It delivers nicotine by heating a vape liquid containing nicotine, flavoring agents, and different solvents into an aerosol [133]. The aerosol contains different harmful components including (but not limited) flavoring agents, humectants (such as glycerin and propylene glycol), contaminants (such as heavy metals), and harmful solvent byproducts (including formaldehyde and acrolein) in addition to tobacco specific nitrosamines [133,134]. All these substances can harm the cerebrovascular systems and the BBB in a way not too dissimilar from TS $[133,134]$. In fact, Kaisar et al. recently reported that chronic e-cigarette smoking is responsible for disrupting the BBB integrity and promote vascular inflammation. Moreover, it may facilitate the onset of stroke and worsen the condition of post-ischemic brain injury [75]. Another recent study also reported that e-cigarette vaping may decrease neuronal glucose utilization, which could result in increased risk for ischemic brain injury and stroke [135]. Recently, McAlinden et al. suggested that, nicotine-based e-cigarettes or vaping may contribute to the upregulation of ACE2 which may also play an important role in progression and outcome of COVID-19 [136].

\section{Cannabis, COVID-19, and Cerebrovascular-Neurological Diseases}

Cannabis, or marijuana, is the most widely abused recreational drug around the world, which is associated with cerebrovascular and neurological diseases such as stroke, structural and functional changes in the brain, cognitive and behavioral disorders [137]. Compared to TS and e-cigarette, smoking cannabis can also generate ROS and $\Delta$-9-tetrahydrocannabinol (THC), the main component of cannabis which promotes OS as well as inflammation that may result in the onset of ischemic stroke $[138,139]$. Other possible mechanisms behind cerebrovascular-neurological dysfunction related to cannabis smoking include among others cerebral vasoconstriction, cerebral artery luminal stenosis, cerebral auto-dysregulation, and angiopathy [140-143]. A recent report demonstrated that smoking cannabis could deteriorate the condition of COVID-19 patients through airway inflammation [144]. Although no case has been reported on cerebrovascular dysfunction in COVID-19 patients and smoking cannabis yet, cannabis could be a risk factor for developing neurological disorders in COVID-19 patients due to its detrimental effect on the cerebrovascular system. 


\section{Conclusions}

The COVID-19 pandemic has taken a tremendous hit on the individuals and family lives all around the world within a short period. This has left health care providers and researchers unprepared and with a plethora of questions to be answered. For instance, who are more vulnerable to this infection? What are the risk factors associated with the severity of this infection? How to tackle the severity and widespread of this kind of infection in the future?

Most importantly, what are the organs that could get affected by SARS-CoV-2 infection as we need to take care of the current as well as recovered patients in the future. From the above-mentioned case reports, it can be speculated that this virus can affect the CNS along with the lung, heart, and gastrointestinal system. These case reports show the presence of neurological disorders in as high as $36.4 \%$ COVID-19 patients [52]. Yet, the mechanism of CNS invasion by COVID-19 is unknown. One of the probable hypotheses is that it can reach the brain through the olfactory nerve system present in the nasal cavity [145]. However, the presence of SARS-COV, a family member of Coronavirus, in the CSF suggested an alternative mechanism of CNS invasion for this class of viruses [146]. Since the BBB protects the brain parenchyma from viral and bacterial infection, damage to this biological barrier could also lead to the accumulation of deadly viruses like SARS-CoV-2 in the CNS. Several studies, including in our lab, have shown the detrimental effect of tobacco and e-cigarette smoking on BBB integrity. Thus, it can be speculated that smoking could lead to the increased severity of SARS-CoV-2 infection by affecting the viability and integrity of the BBB while promoting the expression levels of ACE2 (the responsible mediator of SARS-CoV-2 cell invasion and proliferation) in endothelial cells, glia, and neurons. Furthermore, increased blood circulatory level of VWF and decrease levels of thrombomodulin promoted by smoking and vaping can dysregulate the blood homeostasis promoting blood coagulation and the formation of unwanted blood clot which severely increases the risk of stroke and cardiovascular disorders. At this stage, it is clear that additional studies will be necessary to validate these hypotheses, including further analyses of autopsy samples from smoking and non-smoking COVID-19 patients or conducting in vivo studies. K18-hACE2 transgenic mouse developed by McCray et al. for SARS-CoV studies along with tobacco smoke exposure rodent models could be useful available animal models for studying pathogenesis of SARS-CoV-2 and evaluating the impact of smoking and vaping on cerebrovascular and neurological dysfunction in COVID-19 patients [147,148].

Author Contributions: S.R.A. conceived the study and prepared the drafting of the manuscript. L.C. assisted with the drafting of the manuscript and preparation of the figures. L.C. also oversaw the entire project and provided funding support. All authors reviewed the manuscript. All authors have read and agreed to the published version of the manuscript.

Funding: This work was supported by the National Institutes of Health/National Institute on Drug Abuse 2R01-DA029121 and 1R01-DA049737 to Luca Cucullo.

Conflicts of Interest: The authors declare no conflicts of interest.

$\begin{array}{ll}\text { Abbreviations } \\ \text { ACE2 } & \text { Angiotensin-converting enzyme 2 } \\ \text { BBB } & \text { Blood-brain barrier } \\ \text { BMVEC } & \text { Brain microvascular endothelial cells } \\ \text { CDC } & \text { Centers for Disease Control and Prevention } \\ \text { CNS } & \text { Central nervous system } \\ \text { COPD } & \text { Chronic Obstructive Pulmonary Disease } \\ \text { DIC } & \text { Dissemination of intravascular coagulation } \\ \text { e-cig } & \text { Electronic cigarette } \\ \text { IL-1 } \beta & \text { Interleukin -1 } \beta \\ \text { IL-6 } & \text { Interleukin-6 } \\ \text { IL-12 } & \text { Interleukin-12 }\end{array}$




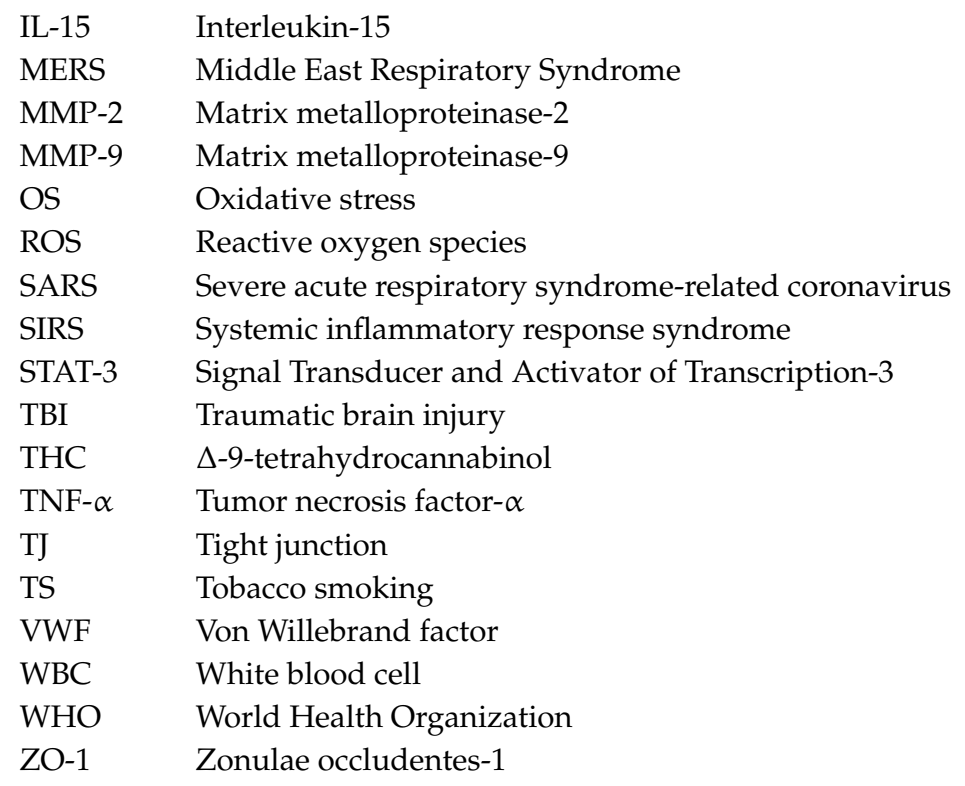

\section{References}

1. Wu, Y.; Xu, X.; Chen, Z.; Duan, J.; Hashimoto, K.; Yang, L.; Liu, C.; Yang, C. Nervous system involvement after infection with COVID-19 and other coronaviruses. Brain Behav. Immun. 2020. [CrossRef] [PubMed]

2. WHO. Coronavirus. Available online: https://www.who.int/health-topics/coronavirus\#tab=tab_1 (accessed on 24 April 2020).

3. Vardavas, C.I.; Nikitara, K. COVID-19 and smoking: A systematic review of the evidence. Tob. Induc. Dis. 2020, 18, 20. [CrossRef] [PubMed]

4. Cucinotta, D.; Vanelli, M. WHO Declares COVID-19 a Pandemic. Acta Biomed. 2020, 91, 157-160. [CrossRef] [PubMed]

5. Coronavirus Cases. Available online: https://www.worldometers.info/coronavirus/ (accessed on 28 May 2020).

6. Pham, H. On estimating the number of deaths related to Covid-19. Mathematics 2020, 8, 655. [CrossRef]

7. Singh, R.K.; Rani, M.; Bhagavathula, A.S.; Sah, R.; Rodriguez-Morales, A.J.; Kalita, H.; Nanda, C.; Sharma, S.; Sharma, Y.D.; Rabaan, A.A.; et al. Prediction of the COVID-19 pandemic for the top 15 affected countries: Advanced autoregressive integrated moving average (ARIMA) model. JMIR Public Health Surveill. 2020, 6, e19115. [CrossRef]

8. Velásquez, R.M.A.; Lara, J.V.M. Forecast and evaluation of COVID-19 spreading in USA with reduced-space gaussian process regression. Chaos Solitons Fractals 2020. [CrossRef]

9. Cui, J.; Li, F.; Shi, Z.L. Origin and evolution of pathogenic coronaviruses. Nat. Rev. Microbiol. 2019, 17, 181-192. [CrossRef]

10. Khan, S.; Siddique, R.; Shereen, M.A.; Ali, A.; Liu, J.; Bai, Q.; Bashir, N.; Xue, M. Emergence of a novel coronavirus, severe acute respiratory syndrome coronavirus 2: Biology and therapeutic options. J. Clin. Microbiol. 2020, 58, e00187-20. [CrossRef]

11. Wu, F.; Zhao, S.; Yu, B.; Chen, Y.-M.; Wang, W.; Song, Z.-G.; Hu, Y.; Tao, Z.-W.; Tian, J.-H.; Pei, Y.-Y. A new coronavirus associated with human respiratory disease in China. Nature 2020, 579, 265-269. [CrossRef]

12. Astuti, I.; Ysrafil, U. Severe acute respiratory syndrome coronavirus 2 (SARS-CoV-2): An overview of viral structure and host response. Diabetes Metab. Syndr. 2020, 14, 407-412. [CrossRef]

13. Hamming, I.; Timens, W.; Bulthuis, M.L.; Lely, A.T.; Navis, G.; van Goor, H. Tissue distribution of ACE2 protein, the functional receptor for SARS coronavirus. A first step in understanding SARS pathogenesis. J. Pathol. 2004, 203, 631-637. [CrossRef] [PubMed]

14. Jiang, S.; Hillyer, C.; Du, L. Neutralizing antibodies against SARS-CoV-2 and other human coronaviruses. Trends Immunol. 2020, 41, 355-359. [CrossRef] [PubMed] 
15. Ghinai, I.; McPherson, T.D.; Hunter, J.C.; Kirking, H.L.; Christiansen, D.; Joshi, K.; Rubin, R.; Morales-Estrada, S.; Black, S.R.; Pacilli, M.; et al. First known person-to-person transmission of severe acute respiratory syndrome coronavirus 2 (SARS-CoV-2) in the USA. Lancet 2020, 395, 1137-1144. [CrossRef]

16. Heinzerling, A.; Stuckey, M.J.; Scheuer, T. Transmission of COVID-19 to health care personnel during exposures to a hospitalized patient-solano county, California, February 2020. Morb. Mortal Wkly. Rep. 2020, 69, 472-476. [CrossRef] [PubMed]

17. CDC. Symptoms of Coronavirus. Available online: https://www.cdc.gov/coronavirus/2019-ncov/symptomstesting/symptoms.html (accessed on 27 May 2020).

18. Oxley, T.J.; Mocco, J.; Majidi, S.; Kellner, C.P.; Shoirah, H.; Singh, I.P.; De Leacy, R.A.; Shigematsu, T.; Ladner, T.R.; Yaeger, K.A.; et al. Large-vessel stroke as a presenting feature of covid-19 in the young. N. Engl. J. Med. 2020, e60. [CrossRef] [PubMed]

19. Xu, Z.; Shi, L.; Wang, Y.; Zhang, J.; Huang, L.; Zhang, C.; Liu, S.; Zhao, P.; Liu, H.; Zhu, L.; et al. Pathological findings of COVID-19 associated with acute respiratory distress syndrome. Lancet Respir. Med. 2020, 8, 420-422. [CrossRef]

20. Moriguchi, T.; Harii, N.; Goto, J.; Harada, D.; Sugawara, H.; Takamino, J.; Ueno, M.; Sakata, H.; Kondo, K.; Myose, N.; et al. A first case of meningitis/encephalitis associated with SARS-coronavirus-2. Int. J. Infect. Dis. 2020, 94, 55-58. [CrossRef]

21. Hikichi, M.; Mizumura, K.; Maruoka, S.; Gon, Y. Pathogenesis of chronic obstructive pulmonary disease (COPD) induced by cigarette smoke. J. Thorac. Dis. 2019, 11, S2129-S2140. [CrossRef]

22. Eapen, M.S.; Sharma, P.; Gaikwad, A.V.; Lu, W.; Myers, S.; Hansbro, P.M.; Sohal, S.S. Epithelial-mesenchymal transition is driven by transcriptional and post transcriptional modulations in COPD: Implications for disease progression and new therapeutics. Int. J. Chron. Obs. Pulmon. Dis. 2019, 14, 1603-1610. [CrossRef]

23. West, R. Tobacco smoking: Health impact, prevalence, correlates and interventions. Psychol. Health 2017, 32, 1018-1036. [CrossRef]

24. Brake, S.J.; Barnsley, K.; Lu, W.; McAlinden, K.D.; Eapen, M.S.; Sohal, S.S. Smoking upregulates angiotensin-converting enzyme-2 receptor: A potential adhesion site for novel coronavirus SARS-CoV-2 (Covid-19). J. Clin. Med. 2020, 9, 841. [CrossRef] [PubMed]

25. Lawrence, H.; Hunter, A.; Murray, R.; Lim, W.S.; McKeever, T. Cigarette smoking and the occurrence of influenza: Systematic review. J. Infect. 2019, 79, 401-406. [CrossRef] [PubMed]

26. Godoy, P.; Castilla, J.; Mayoral, J.M.; Delgado-Rodriguez, M.; Martin, V.; Astray, J.; Soldevila, N.; Gonzalez-Candelas, F.; Castro, A.; Baricot, M.; et al. Smoking may increase the risk of hospitalization due to influenza. Eur. J. Public Health 2016, 26, 882-887. [CrossRef] [PubMed]

27. Han, L.; Ran, J.; Mak, Y.W.; Suen, L.K.; Lee, P.H.; Peiris, J.S.M.; Yang, L. Smoking and Influenza-associated Morbidity and mortality: A systematic review and meta-analysis. Epidemiology 2019, 30, 405-417. [CrossRef] [PubMed]

28. Kaisar, M.A.; Sivandzade, F.; Bhalerao, A.; Cucullo, L. Conventional and electronic cigarettes dysregulate the expression of iron transporters and detoxifying enzymes at the brain vascular endothelium: In vivo evidence of a gender-specific cellular response to chronic cigarette smoke exposure. Neurosci. Lett. 2018, 682, 1-9. [CrossRef]

29. Sajja, R.K.; Rahman, S.; Cucullo, L. Drugs of abuse and blood-brain barrier endothelial dysfunction: A focus on the role of oxidative stress. J. Cereb. Blood Flow Metab. 2016, 36, 539-554. [CrossRef]

30. Sajja, R.K.; Naik, P.; Cucullo, L. Differential cerebrovascular toxicity of various tobacco products: A regulatory perspective. J. Pharm. 2015, 3. [CrossRef]

31. Naik, P.; Cucullo, L. Pathobiology of tobacco smoking and neurovascular disorders: Untied strings and alternative products. Fluids Barriers CNS 2015, 12, 25. [CrossRef]

32. Zhou, F.; Yu, T.; Du, R.; Fan, G.; Liu, Y.; Liu, Z.; Xiang, J.; Wang, Y.; Song, B.; Gu, X.; et al. Clinical course and risk factors for mortality of adult inpatients with COVID-19 in Wuhan, China: A retrospective cohort study. Lancet 2020, 395, 1054-1062. [CrossRef]

33. Huang, C.; Wang, Y.; Li, X.; Ren, L.; Zhao, J.; Hu, Y.; Zhang, L.; Fan, G.; Xu, J.; Gu, X.; et al. Clinical features of patients infected with 2019 novel coronavirus in Wuhan, China. Lancet 2020, 395, 497-506. [CrossRef]

34. Guan, W.J.; Ni, Z.Y.; Hu, Y.; Liang, W.H.; Ou, C.Q.; He, J.X.; Liu, L.; Shan, H.; Lei, C.L.; Hui, D.S.C.; et al. Clinical characteristics of coronavirus disease 2019 in China. N. Engl. J. Med. 2020. [CrossRef] [PubMed] 
35. Liu, W.; Tao, Z.W.; Lei, W.; Ming-Li, Y.; Kui, L.; Ling, Z.; Shuang, W.; Yan, D.; Jing, L.; Liu, H.G.; et al. Analysis of factors associated with disease outcomes in hospitalized patients with 2019 novel coronavirus disease. Chin. Med. J. 2020. [CrossRef] [PubMed]

36. Michalicova, A.; Bhide, K.; Bhide, M.; Kovac, A. How viruses infiltrate the central nervous system. Acta Virol. 2017, 61, 393-400. [CrossRef] [PubMed]

37. Al-Obaidi, M.M.J.; Bahadoran, A.; Wang, S.M.; Manikam, R.; Raju, C.S.; Sekaran, S.D. Disruption of the blood brain barrier is vital property of neurotropic viral infection of the central nervous system. Acta Virol. 2018, 62, 16-27. [CrossRef] [PubMed]

38. Soung, A.; Klein, R.S. Viral encephalitis and neurologic diseases: Focus on astrocytes. Trends Mol. Med. 2018, 24, 950-962. [CrossRef] [PubMed]

39. Elkind, M.S. Why now? Moving from stroke risk factors to stroke triggers. Curr. Opin. Neurol. 2007, 20, 51-57. [CrossRef]

40. Warren-Gash, C.; Blackburn, R.; Whitaker, H.; McMenamin, J.; Hayward, A.C. Laboratory-confirmed respiratory infections as triggers for acute myocardial infarction and stroke: A self-controlled case series analysis of national linked datasets from Scotland. Eur. Respir. J. 2018, 51. [CrossRef]

41. Muhammad, S.; Haasbach, E.; Kotchourko, M.; Strigli, A.; Krenz, A.; Ridder, D.A.; Vogel, A.B.; Marti, H.H.; Al-Abed, Y.; Planz, O.; et al. Influenza virus infection aggravates stroke outcome. Stroke 2011, 42, 783-791. [CrossRef]

42. Tsai, L.K.; Hsieh, S.T.; Chang, Y.C. Neurological manifestations in severe acute respiratory syndrome. Acta Neurol. Taiwan 2005, 14, 113-119.

43. Gu, J.; Gong, E.; Zhang, B.; Zheng, J.; Gao, Z.; Zhong, Y.; Zou, W.; Zhan, J.; Wang, S.; Xie, Z.; et al. Multiple organ infection and the pathogenesis of SARS. J. Exp. Med. 2005, 202, 415-424. [CrossRef]

44. Zhang, Q.L.; Ding, Y.Q.; Hou, J.L.; He, L.; Huang, Z.X.; Wang, H.J.; Cai, J.J.; Zhang, J.H.; Zhang, W.L.; Geng, J.; et al. Detection of severe acute respiratory syndrome (SARS)-associated coronavirus RNA in autopsy tissues with in situ hybridization. Di Yi Jun Yi Da Xue Xue Bao 2003, 23, 1125-1127. [PubMed]

45. Saad, M.; Omrani, A.S.; Baig, K.; Bahloul, A.; Elzein, F.; Matin, M.A.; Selim, M.A.; Al Mutairi, M.; Al Nakhli, D.; Al Aidaroos, A.Y.; et al. Clinical aspects and outcomes of 70 patients with Middle East respiratory syndrome coronavirus infection: a single-center experience in Saudi Arabia. Int. J. Infect. Dis. 2014, 29, 301-306. [CrossRef] [PubMed]

46. Kim, J.E.; Heo, J.H.; Kim, H.O.; Song, S.H.; Park, S.S.; Park, T.H.; Ahn, J.Y.; Kim, M.K.; Choi, J.P. Neurological complications during treatment of middle east respiratory syndrome. J. Clin. Neurol. 2017, 13, 227-233. [CrossRef] [PubMed]

47. Wu, A.; Peng, Y.; Huang, B.; Ding, X.; Wang, X.; Niu, P.; Meng, J.; Zhu, Z.; Zhang, Z.; Wang, J.; et al. Genome composition and divergence of the novel coronavirus (2019-nCoV) originating in China. Cell Host Microbe 2020, 27, 325-328. [CrossRef] [PubMed]

48. Kim, J.M.; Chung, Y.S.; Jo, H.J.; Lee, N.J.; Kim, M.S.; Woo, S.H.; Park, S.; Kim, J.W.; Kim, H.M.; Han, M.G. Identification of coronavirus isolated from a patient in Korea with COVID-19. Osong Public Health Res. Perspect. 2020, 11, 3-7. [CrossRef]

49. Wang, H.Y.; Li, X.L.; Yan, Z.R.; Sun, X.P.; Han, J.; Zhang, B.W. Potential neurological symptoms of COVID-19. Adv. Neurol. Disord. 2020, 13. [CrossRef]

50. Giacomelli, A.; Pezzati, L.; Conti, F.; Bernacchia, D.; Siano, M.; Oreni, L.; Rusconi, S.; Gervasoni, C.; Ridolfo, A.L.; Rizzardini, G.; et al. Self-reported olfactory and taste disorders in SARS-CoV-2 patients: A cross-sectional study. Clin. Infect. Dis. 2020. [CrossRef]

51. Miller, R.W. There's a New Symptom of Coronavirus, Doctors Say: Sudden Loss of Smell or Taste. Available online: https:/www.usatoday.com/story/news/health/2020/03/24/coronavirus-symptoms-loss-smell-taste/ 2897385001/ (accessed on 28 April 2020).

52. Mao, L.; Wang, M.; Chen, S.; He, Q.; Chang, J.; Hong, C.; Zhou, Y.; Wang, D.; Jin, H.; Hu, B. Neurological manifestations of hospitalized patients with COVID-19 in Wuhan, China: A retrospective case series study. medRxiv 2020. [CrossRef]

53. Asadi-Pooya, A.A.; Simani, L. Central nervous system manifestations of COVID-19: A systematic review. J. Neurol. Sci. 2020, 413, 116832. [CrossRef] 
54. Chen, T.; Wu, D.; Chen, H.; Yan, W.; Yang, D.; Chen, G.; Ma, K.; Xu, D.; Yu, H.; Wang, H.; et al. Clinical characteristics of 113 deceased patients with coronavirus disease 2019: retrospective study. BMJ 2020, 368, m1091. [CrossRef]

55. Li, Y.; Wang, M.; Zhou, Y.; Chang, J.; Xian, Y.; Mao, L.; Hong, C.; Chen, S.; Wang, Y.; Wang, H.; et al. Acute cerebrovascular disease following COVID-19: A single center, retrospective, observational study. Lancet 2020. [CrossRef]

56. Wang, D.; Hu, B.; Hu, C.; Zhu, F.; Liu, X.; Zhang, J.; Wang, B.; Xiang, H.; Cheng, Z.; Xiong, Y.; et al. Clinical characteristics of 138 hospitalized patients with 2019 novel coronavirus-infected pneumonia in Wuhan, China. JAMA 2020. [CrossRef] [PubMed]

57. Chen, N.; Zhou, M.; Dong, X.; Qu, J.; Gong, F.; Han, Y.; Qiu, Y.; Wang, J.; Liu, Y.; Wei, Y.; et al. Epidemiological and clinical characteristics of 99 cases of 2019 novel coronavirus pneumonia in Wuhan, China: A descriptive study. Lancet 2020, 395, 507-513. [CrossRef]

58. Yang, X.; Yu, Y.; Xu, J.; Shu, H.; Xia, J.; Liu, H.; Wu, Y.; Zhang, L.; Yu, Z.; Fang, M.; et al. Clinical course and outcomes of critically ill patients with SARS-CoV-2 pneumonia in Wuhan, China: A single-centered, retrospective, observational study. Lancet Respir. Med. 2020. [CrossRef]

59. Guo, Y.R.; Cao, Q.D.; Hong, Z.S.; Tan, Y.Y.; Chen, S.D.; Jin, H.J.; Tan, K.S.; Wang, D.Y.; Yan, Y. The origin, transmission and clinical therapies on coronavirus disease 2019 (COVID-19) outbreak-an update on the status. Mil. Med. Res. 2020, 7, 11. [CrossRef] [PubMed]

60. Mao, L.; Jin, H.; Wang, M.; Hu, Y.; Chen, S.; He, Q.; Chang, J.; Hong, C.; Zhou, Y.; Wang, D.; et al. Neurologic manifestations of hospitalized patients with coronavirus disease 2019 in Wuhan, China. JAMA Neurol. 2020. [CrossRef] [PubMed]

61. Mehta, P.; McAuley, D.F.; Brown, M.; Sanchez, E.; Tattersall, R.S.; Manson, J.J. Hlh across speciality collaboration, U.K. COVID-19: consider cytokine storm syndromes and immunosuppression. Lancet 2020, 395, 1033-1034. [CrossRef]

62. Chen, C.; Zhang, X.R.; Ju, Z.Y.; He, W.F. Advances in the research of cytokine storm mechanism induced by corona virus disease 2019 and the corresponding immunotherapies. Zhonghua Shao Shang Za Zhi 2020, 36, E005. [CrossRef]

63. Tisoncik, J.R.; Korth, M.J.; Simmons, C.P.; Farrar, J.; Martin, T.R.; Katze, M.G. Into the eye of the cytokine storm. Microbiol. Mol. Biol. Rev. 2012, 76, 16-32. [CrossRef]

64. Wang, Y.; Wang, Y.; Chen, Y.; Qin, Q. Unique epidemiological and clinical features of the emerging 2019 novel coronavirus pneumonia (COVID-19) implicate special control measures. J. Med. Virol. 2020. [CrossRef]

65. Donoghue, M.; Hsieh, F.; Baronas, E.; Godbout, K.; Gosselin, M.; Stagliano, N.; Donovan, M.; Woolf, B.; Robison, K.; Jeyaseelan, R.; et al. A novel angiotensin-converting enzyme-related carboxypeptidase (ACE2) converts angiotensin I to angiotensin 1-9. Circ. Res. 2000, 87, E1-E9. [CrossRef] [PubMed]

66. Tipnis, S.R.; Hooper, N.M.; Hyde, R.; Karran, E.; Christie, G.; Turner, A.J. A human homolog of angiotensin-converting enzyme. Cloning and functional expression as a captopril-insensitive carboxypeptidase. J. Biol. Chem. 2000, 275, 33238-33243. [CrossRef] [PubMed]

67. Baig, A.M.; Khaleeq, A.; Ali, U.; Syeda, H. Evidence of the COVID-19 virus targeting the CNS: Tissue distribution, host-virus interaction, and proposed neurotropic mechanisms. ACS Chem. Neurosci. 2020, 11, 995-998. [CrossRef] [PubMed]

68. Miller, A.J.; Arnold, A.C. The renin-angiotensin system in cardiovascular autonomic control: Recent developments and clinical implications. Clin. Auton. Res. 2019, 29, 231-243. [CrossRef] [PubMed]

69. Hoffmann, M.; Kleine-Weber, H.; Schroeder, S.; Kruger, N.; Herrler, T.; Erichsen, S.; Schiergens, T.S.; Herrler, G.; Wu, N.H.; Nitsche, A.; et al. SARS-CoV-2 cell entry depends on ACE2 and TMPRSS2 and is blocked by a clinically proven protease inhibitor. Cell 2020, 181, 271-280. [CrossRef]

70. Letko, M.; Marzi, A.; Munster, V. Functional assessment of cell entry and receptor usage for SARS-CoV-2 and other lineage B betacoronaviruses. Nat. Microbiol. 2020, 5, 562-569. [CrossRef]

71. Williams, V.R.; Scholey, J.W. Angiotensin-converting enzyme 2 and renal disease. Curr. Opin. Nephrol. Hypertens. 2018, 27, 35-41. [CrossRef]

72. Verdecchia, P.; Cavallini, C.; Spanevello, A.; Angeli, F. The pivotal link between ACE2 deficiency and SARS-CoV-2 infection. Eur. J. Intern. Med. 2020, S0953-S6205. [CrossRef] 
73. Chen, Z.M.; Fu, J.F.; Shu, Q.; Chen, Y.H.; Hua, C.Z.; Li, F.B.; Lin, R.; Tang, L.F.; Wang, T.L.; Wang, W.; et al. Diagnosis and treatment recommendations for pediatric respiratory infection caused by the 2019 novel coronavirus. World J. Pediatr. 2020. [CrossRef]

74. Hossain, M.; Sathe, T.; Fazio, V.; Mazzone, P.; Weksler, B.; Janigro, D.; Rapp, E.; Cucullo, L. Tobacco smoke: A critical etiological factor for vascular impairment at the blood-brain barrier. Brain Res. 2009, 1287, 192-205. [CrossRef]

75. Kaisar, M.A.; Villalba, H.; Prasad, S.; Liles, T.; Sifat, A.E.; Sajja, R.K.; Abbruscato, T.J.; Cucullo, L. Offsetting the impact of smoking and e-cigarette vaping on the cerebrovascular system and stroke injury: Is Metformin a viable countermeasure? Redox Biol. 2017, 13, 353-362. [CrossRef] [PubMed]

76. Klein, R.S.; Garber, C.; Howard, N. Infectious immunity in the central nervous system and brain function. Nat. Immunol. 2017, 18, 132-141. [CrossRef] [PubMed]

77. Fu, Y.; Cheng, Y.; Wu, Y. Understanding SARS-CoV-2-mediated inflammatory responses: From mechanisms to potential therapeutic tools. Virol. Sin. 2020. [CrossRef] [PubMed]

78. Yin, C.H.; Wang, C.; Tang, Z.; Wen, Y.; Zhang, S.W.; Wang, B.E. Clinical analysis of multiple organ dysfunction syndrome in patients suffering from SARS. Zhongguo Wei Zhong Bing Ji Jiu Yi Xue 2004, 16, 646-650. [PubMed]

79. Ulhaq, Z.S.; Soraya, G.V. Interleukin-6 as a potential biomarker of COVID-19 progression. Med. Mal. Infect. 2020, 50, 382-383. [CrossRef] [PubMed]

80. Bohmwald, K.; Galvez, N.M.S.; Rios, M.; Kalergis, A.M. Neurologic alterations due to respiratory virus infections. Front. Cell Neurosci. 2018, 12, 386. [CrossRef]

81. Wan, S.; Yi, Q.; Fan, S.; Lv, J.; Zhang, X.; Guo, L.; Lang, C.; Xiao, Q.; Xiao, K.; Yi, Z.; et al. Characteristics of lymphocyte subsets and cytokines in peripheral blood of 123 hospitalized patients with 2019 novel coronavirus pneumonia (NCP). medRxiv 2020. [CrossRef]

82. Li, Y.; Fu, L.; Gonzales, D.M.; Lavi, E. Coronavirus neurovirulence correlates with the ability of the virus to induce proinflammatory cytokine signals from astrocytes and microglia. J. Virol. 2004, 78, 3398-3406. [CrossRef]

83. Abdennour, L.; Zeghal, C.; Deme, M.; Puybasset, L. Interaction brain-lungs. Ann. Fr. Anesth. Reanim. 2012, 31, e101-e107. [CrossRef]

84. Pappas, S. 'Silent Hypoxia' May be Killing COVID-19 Patients. But There's Hope. Available online: https://www.livescience.com/silent-hypoxia-killing-covid-19-coronavirus-patients.html (accessed on 2 May 2020).

85. Ferrario, C.M.; Trask, A.J.; Jessup, J.A. Advances in biochemical and functional roles of angiotensin-converting enzyme 2 and angiotensin-(1-7) in regulation of cardiovascular function. Am. J. Physiol. Heart Circ. Physiol. 2005, 289, H2281-H2290. [CrossRef]

86. Mori, I. Transolfactory neuroinvasion by viruses threatens the human brain. Acta Virol. 2015, 59, 338-349. [CrossRef] [PubMed]

87. Desforges, M.; Le Coupanec, A.; Dubeau, P.; Bourgouin, A.; Lajoie, L.; Dube, M.; Talbot, P.J. Human coronaviruses and other respiratory viruses: Underestimated opportunistic pathogens of the central nervous system? Viruses 2019, 12, 14. [CrossRef] [PubMed]

88. Bhalerao, A.; Cucullo, L. Impact of tobacco smoke in HIV progression: a major risk factor for the development of NeuroAIDS and associated CNS disorders. J. Public Health 2019, 8. [CrossRef]

89. CDC. Health Effects of Cigarette Smoking. Available online: https://www.cdc.gov/tobacco/data_statistics/ fact_sheets/health_effects/effects_cig_smoking/index.htm (accessed on 27 May 2020).

90. Sivandzade, F.; Alqahtani, F.; Cucullo, L. Molecular sciences traumatic brain injury and blood-brain barrier (BBB): Underlying pathophysiological mechanisms and the influence of cigarette smoking as a premorbid condition. Int. J. Mol. Sci. 2020, 21, 2721. [CrossRef]

91. Domino, E.F. Tobacco smoking and MRI/MRS brain abnormalities compared to nonsmokers. Prog. Neuropsychopharmacol. Biol. Psychiatry 2008, 32, 1778-1781. [CrossRef]

92. Zhong, G.; Wang, Y.; Zhang, Y.; Guo, J.J.; Zhao, Y. Smoking is associated with an increased risk of dementia: A meta-analysis of prospective cohort studies with investigation of potential effect modifiers. PLoS ONE 2015, 10, e0118333. [CrossRef]

93. Di Napoli, V.A.; Huber, J.D.; Houser, K.; Li, X.; Rosen, C.L. Early disruptions of the blood-brain barrier may contribute to exacerbated neuronal damage and prolonged functional recovery following stroke in aged rats. Neurobiol. Aging 2008, 29, 753-764. [CrossRef] 
94. Marchi, N.; Angelov, L.; Masaryk, T.; Fazio, V.; Granata, T.; Hernandez, N.; Hallene, K.; Diglaw, T.; Franic, L.; Najm, I.; et al. Seizure-promoting effect of blood-brain barrier disruption. Epilepsia 2007, 48, 732-742. [CrossRef]

95. Howard, G.; Wagenknecht, L.E.; Cai, J.; Cooper, L.; Kraut, M.A.; Toole, J.F. Cigarette smoking and other risk factors for silent cerebral infarction in the general population. Stroke 1998, 29, 913-917. [CrossRef]

96. Gill, J.S.; Shipley, M.J.; Tsementzis, S.A.; Hornby, R.; Gill, S.K.; Hitchcock, E.R.; Beevers, D.G. Cigarette smoking. A risk factor for hemorrhagic and nonhemorrhagic stroke. Arch. Intern. Med. 1989, 149, $2053-2057$. [CrossRef]

97. Sivandzade, F.; Alqahtani, F.; Sifat, A.; Cucullo, L. The cerebrovascular and neurological impact of chronic smoking on post-traumatic brain injury outcome and recovery: an in vivo study. J. Neuroinflammation 2020, 17, 133. [CrossRef] [PubMed]

98. Prasad, S.; Cucullo, L. Impact of tobacco smoking and type-2 diabetes mellitus on public health: A cerebrovascular perspective. J. Pharmacovigil. 2015, 2. [CrossRef] [PubMed]

99. Hossain, M.; Mazzone, P.; Tierney, W.; Cucullo, L. In vitro assessment of tobacco smoke toxicity at the BBB: Do antioxidant supplements have a protective role? BMC Neurosci. 2011, 12, 92. [CrossRef] [PubMed]

100. Mazzone, P.; Tierney, W.; Hossain, M.; Puvenna, V.; Janigro, D.; Cucullo, L. Pathophysiological impact of cigarette smoke exposure on the cerebrovascular system with a focus on the blood-brain barrier: Expanding the awareness of smoking toxicity in an underappreciated area. Int. J. Environ. Res. Public Health 2010, 7, 4111-4126. [CrossRef]

101. Kaisar, M.A.; Prasad, S.; Cucullo, L. Protecting the BBB endothelium against cigarette smoke-induced oxidative stress using popular antioxidants: Are they really beneficial? Brain Res. 2015, 1627, 90-100. [CrossRef]

102. Rosenberg, G.A. Matrix metalloproteinases in neuroinflammation. Glia 2002, 39, 279-291. [CrossRef]

103. Hawkins, B.T.; Abbruscato, T.J.; Egleton, R.D.; Brown, R.C.; Huber, J.D.; Campos, C.R.; Davis, T.P. Nicotine increases in vivo blood-brain barrier permeability and alters cerebral microvascular tight junction protein distribution. Brain Res. 2004, 1027, 48-58. [CrossRef]

104. Paulson, J.R.; Roder, K.E.; McAfee, G.; Allen, D.D.; Van der Schyf, C.J.; Abbruscato, T.J. Tobacco smoke chemicals attenuate brain-to-blood potassium transport mediated by the $\mathrm{Na}, \mathrm{K}, 2 \mathrm{Cl}$-cotransporter during hypoxia-reoxygenation. J. Pharm. Exp. 2006, 316, 248-254. [CrossRef]

105. Paulson, J.R.; Yang, T.; Selvaraj, P.K.; Mdzinarishvili, A.; Van der Schyf, C.J.; Klein, J.; Bickel, U.; Abbruscato, T.J. Nicotine exacerbates brain edema during in vitro and in vivo focal ischemic conditions. J. Pharm. Exp. 2010, 332, 371-379. [CrossRef]

106. Prasad, S.; Sajja, R.K.; Park, J.H.; Naik, P.; Kaisar, M.A.; Cucullo, L. Impact of cigarette smoke extract and hyperglycemic conditions on blood-brain barrier endothelial cells. Fluids Barriers CNS 2015, 12, 18. [CrossRef]

107. Geraghty, P.; Wyman, A.; Garcia-Arcos, I.; Dabo, A.; Gadhvi, S.; Foronjy, R. STAT3 modulates cigarette smoke-induced inflammation and protease expression. Front. Physiol. 2013, 4. [CrossRef] [PubMed]

108. Villapol, S.; Kryndushkin, D.; Balarezo, M.G.; Campbell, A.M.; Saavedra, J.M.; Shewmaker, F.P.; Symes, A.J. Hepatic expression of serum amyloid A1 is induced by traumatic brain injury and modulated by telmisartan. Am. J. Pathol. 2015, 185, 2641-2652. [CrossRef] [PubMed]

109. Hartz, A.M.; Bauer, B.; Soldner, E.L.; Wolf, A.; Boy, S.; Backhaus, R.; Mihaljevic, I.; Bogdahn, U.; Klunemann, H.H.; Schuierer, G.; et al. Amyloid-beta contributes to blood-brain barrier leakage in transgenic human amyloid precursor protein mice and in humans with cerebral amyloid angiopathy. Stroke 2012, 43, 514-523. [CrossRef] [PubMed]

110. Circu, M.L.; Aw, T.Y. Reactive oxygen species, cellular redox systems, and apoptosis. Free Radic. Biol. Med. 2010, 48, 749-762. [CrossRef]

111. Chen, H.W.; Chien, M.L.; Chaung, Y.H.; Lii, C.K.; Wang, T.S. Extracts from cigarette smoke induce DNA damage and cell adhesion molecule expression through different pathways. Chem. Biol. Interact 2004, 150, 233-241. [CrossRef]

112. DeMarini, D.M. Genotoxicity of tobacco smoke and tobacco smoke condensate: A review. Mutat. Res. 2004, 567, 447-474. [CrossRef]

113. Pryor, W.A.; Stone, K.; Zang, L.-Y.; Bermúdez, E. Fractionation of aqueous cigarette tar extracts: Fractions that contain the tar radical cause DNA damage. Chem. Res. Toxicol. 1998, 11, 441-448. [CrossRef] 
114. Pfeifer, G.P.; Denissenko, M.F.; Olivier, M.; Tretyakova, N.; Hecht, S.S.; Hainaut, P. Tobacco smoke carcinogens, DNA damage and p53 mutations in smoking-associated cancers. Oncogene 2002, 21, 7435-7451. [CrossRef]

115. Bernardi, L.; Casucci, G.; Haider, T.; Brandstatter, E.; Pocecco, E.; Ehrenbourg, I.; Burtscher, M. Autonomic and cerebrovascular abnormalities in mild COPD are worsened by chronic smoking. Eur. Respir. J. 2008, 32, 1458-1465. [CrossRef]

116. Arcavi, L.; Benowitz, N.L. Cigarette smoking and infection. Arch. Intern. Med. 2004, 164, $2206-2216$. [CrossRef]

117. Farrokhi, F.R.; Marsans, M.T.; Sikora, M.; Monsell, S.E.; Wright, A.K.; Palmer, M.; Hoefer, A.; McLeod, P.; Mark, J.; Carlson, J. Pre-operative smoking history increases risk of infection in deep brain stimulation surgery. J. Clin. Neurosci. 2019, 69, 88-92. [CrossRef] [PubMed]

118. Smith, J.C.; Sheltzer, J.M. Cigarette smoke triggers the expansion of a subpopulation of respiratory epithelial cells that express the SARS-CoV-2 receptor ACE2. bioRxiv 2020. [CrossRef]

119. Monteil, V.; Kwon, H.; Prado, P.; Hagelkruys, A.; Wimmer, R.A.; Stahl, M.; Leopoldi, A.; Garreta, E.; Hurtado Del Pozo, C.; Prosper, F.; et al. Inhibition of SARS-CoV-2 infections in engineered human tissues using clinical-grade soluble human ACE2. Cell 2020. [CrossRef] [PubMed]

120. Li, W.; Moore, M.J.; Vasilieva, N.; Sui, J.; Wong, S.K.; Berne, M.A.; Somasundaran, M.; Sullivan, J.L.; Luzuriaga, K.; Greenough, T.C.; et al. Angiotensin-converting enzyme 2 is a functional receptor for the SARS coronavirus. Nature 2003, 426, 450-454. [CrossRef] [PubMed]

121. Auer, R.; Concha-Lozano, N.; Jacot-Sadowski, I.; Cornuz, J.; Berthet, A. Heat-not-burn tobacco cigarettes: Smoke by any other name. JAMA Intern. Med. 2017, 177, 1050-1052. [CrossRef]

122. Netland, J.; Meyerholz, D.K.; Moore, S.; Cassell, M.; Perlman, S. Severe acute respiratory syndrome coronavirus infection causes neuronal death in the absence of encephalitis in mice transgenic for human ACE2. J. Virol. 2008, 82, 7264-7275. [CrossRef]

123. Escher, R.; Breakey, N.; Lammle, B. Severe COVID-19 infection associated with endothelial activation. Thromb. Res. 2020, 190, 62. [CrossRef]

124. Panigada, M.; Bottino, N.; Tagliabue, P.; Grasselli, G.; Novembrino, C.; Chantarangkul, V.; Pesenti, A.; Peyvandi, F.; Tripodi, A. Hypercoagulability of COVID-19 patients in intensive care unit. A report of thromboelastography findings and other parameters of hemostasis. J. Thromb. Haemost. 2020. [CrossRef]

125. Lip, G.Y.; Blann, A. Von Willebrand factor: A marker of endothelial dysfunction in vascular disorders? Cardiovasc. Res. 1997, 34, 255-265. [CrossRef]

126. Prasad, S.; Sajja, R.K.; Kaisar, M.A.; Park, J.H.; Villalba, H.; Liles, T.; Abbruscato, T.; Cucullo, L. Role of Nrf2 and protective effects of Metformin against tobacco smoke-induced cerebrovascular toxicity. Redox Biol. 2017, 12, 58-69. [CrossRef]

127. Al-Awadhi, A.M.; AlFadhli, S.M.; Mustafa, N.Y.; Sharma, P.N. Effects of cigarette smoking on hematological parameters and von Willebrand factor functional activity levels in asymptomatic male and female Arab smokers. Med. Princ. Pr. 2008, 17, 149-153. [CrossRef] [PubMed]

128. Wannamethee, S.G.; Lowe, G.D.; Shaper, A.G.; Rumley, A.; Lennon, L.; Whincup, P.H. Associations between cigarette smoking, pipe/cigar smoking, and smoking cessation, and haemostatic and inflammatory markers for cardiovascular disease. Eur. Heart J. 2005, 26, 1765-1773. [CrossRef] [PubMed]

129. Connors, J.M.; Levy, J.H. COVID-19 and its implications for thrombosis and anticoagulation. Blood 2020. [CrossRef] [PubMed]

130. Song, J.C.; Wang, G.; Zhang, W.; Zhang, Y.; Li, W.Q.; Zhou, Z.; People's Liberation Army Professional Committee of Critical Care Medicine; Chinese Society on Thrombosis and Haemostasis. Chinese expert consensus on diagnosis and treatment of coagulation dysfunction in COVID-19. Mil. Med. Res. 2020, 7, 19. [CrossRef]

131. Cui, S.; Chen, S.; Li, X.; Liu, S.; Wang, F. Prevalence of venous thromboembolism in patients with severe novel coronavirus pneumonia. J. Thromb. Haemost. 2020. [CrossRef]

132. Russo, P.; Bonassi, S.; Giacconi, R.; Malavolta, M.; Tomino, C.; Maggi, F. COVID-19 and smoking. Is nicotine the hidden link? Eur. Respir. J. 2020. [CrossRef]

133. Bhalerao, A.; Sivandzade, F.; Archie, S.; Cucullo, L. Public health policies on e-cigarettes. Curr. Cardiol. Rep. 2019, 21. [CrossRef] 
134. Heldt, N.A.; Seliga, A.; Winfield, M.; Gajghate, S.; Reichenbach, N.; Yu, X.; Rom, S.; Tenneti, A.; May, D.; Gregory, B.D.; et al. Electronic cigarette exposure disrupts blood-brain barrier integrity and promotes neuroinflammation. Brain Behav. Immun. 2020. [CrossRef]

135. Sifat, A.E.; Nozohouri, S.; Villalba, H.; Al Shoyaib, A.; Vaidya, B.; Karamyan, V.T.; Abbruscato, T. Prenatal electronic cigarette exposure decreases brain glucose utilization and worsens outcome in offspring hypoxic-ischemic brain injury. J. Neurochem. 2020, 153, 63-79. [CrossRef]

136. McAlinden, K.D.; Eapen, M.S.; Lu, W.; Chia, C.; Haug, G.; Sohal, S.S. COVID-19 and vaping: Risk for increased susceptibility to SARS-CoV-2 infection? Eur. Respir. J. 2020. [CrossRef]

137. Archie, S.; Cucullo, L. Harmful effects of smoking cannabis: A cerebrovascular and neurological perspective. Front. Pharmacol. 2019, 10. [CrossRef] [PubMed]

138. Wolff, V.; Schlagowski, A.I.; Rouyer, O.; Charles, A.L.; Singh, F.; Auger, C.; Schini-Kerth, V.; Marescaux, C.; Raul, J.S.; Zoll, J.; et al. Tetrahydrocannabinol induces brain mitochondrial respiratory chain dysfunction and increases oxidative stress: A potential mechanism involved in cannabis-related stroke. Biomed. Res. Int. 2015, 2015, 323706. [CrossRef] [PubMed]

139. Goyal, H.; Awad, H.H.; Ghali, J.K. Role of cannabis in cardiovascular disorders. J. Thorac. Dis. 2017, 9, 2079-2092. [CrossRef] [PubMed]

140. Chadwick, B.; Miller, M.; Hurd, Y. Cannabis use during adolescent development: Susceptibility to psychiatric illness. Front. Psychiatry 2013, 4. [CrossRef] [PubMed]

141. Battistella, G.; Fornari, E.; Annoni, J.-M.; Chtioui, H.; Dao, K.; Fabritius, M.; Favrat, B.; Mall, J.-F.; Maeder, P.; Giroud, C. Long-term effects of cannabis on brain structure. Neuropsychopharmacology 2014, 39, 2041-2048. [CrossRef] [PubMed]

142. Broyd, S.J.; van Hell, H.H.; Beale, C.; Yücel, M.; Solowij, N. Acute and chronic effects of cannabinoids on human cognition-A systematic review. Biol. Psychiatry 2016, 79, 557-567. [CrossRef]

143. Szutorisz, H.; Hurd, Y.L. High times for cannabis: Epigenetic imprint and its legacy on brain and behavior. Neurosci. Biobehav. Rev. 2018, 85, 93-101. [CrossRef]

144. LaMotte, S. Smoking weed and coronavirus: Even occasional use raises risk of Covid-19 complications. Available online: https://www.cnn.com/2020/04/10/health/smoking-weed-coronavirus-wellness/index.html (accessed on 20 April 2020).

145. Li, Y.C.; Bai, W.Z.; Hashikawa, T. The neuroinvasive potential of SARS-CoV2 may play a role in the respiratory failure of COVID-19 patients. J. Med. Virol. 2020. [CrossRef]

146. Lau, K.-K.; Yu, W.-C.; Chu, C.-M.; Lau, S.-T.; Sheng, B.; Yuen, K.-Y. Possible central nervous system infection by SARS coronavirus. Emerg. Infect. Dis. 2004, 10, 342-344. [CrossRef]

147. Leberl, M.; Kratzer, A.; Taraseviciene-Stewart, L. Tobacco smoke induced COPD/emphysema in the animal model-Are we all on the same page? Front. Physiol. 2013, 4. [CrossRef]

148. McCray, P.B., Jr.; Pewe, L.; Wohlford-Lenane, C.; Hickey, M.; Manzel, L.; Shi, L.; Netland, J.; Jia, H.P.; Halabi, C.; Sigmund, C.D.; et al. Lethal infection of K18-hACE2 mice infected with severe acute respiratory syndrome coronavirus. J. Virol. 2007, 81, 813-821. [CrossRef] [PubMed]

(C) 2020 by the authors. Licensee MDPI, Basel, Switzerland. This article is an open access article distributed under the terms and conditions of the Creative Commons Attribution (CC BY) license (http://creativecommons.org/licenses/by/4.0/). 